\title{
THE IMPACT OF E-GOVERNMENT ON THE LEVEL OF CORRUPTION
}

\author{
Maksym Tsutskiridze ${ }^{1}$, Anatoliy Bereza ${ }^{2}$
}

\begin{abstract}
The purpose of the article is to determine the way e-government can reduce corruption in the country and to analyze the dynamics of four indices of corruption in Ukraine. The subject of the research is the features of the civil law nature of electronic money. Methodology. Research methods are chosen based on the object, subject and purpose of the study. When researching, the general scientific and special methods of legal science have been used. Thus, the analysis and synthesis method as well as the logical method have been used to formulate a holistic view on the relationship between e-government and corruption, its features and legal nature. The logical-semantic method has been used to establish the meaning of the concepts "corruption" and "e-government", "inflation". The legal modeling method has been applied to formulate the relevant conclusions and propositions. Results. The potential of e-government impact on the level of corruption in the country is analysed, in particular, depersonification, deregulation and transparency. The main obstacles to the implementation of e-government initiatives (problems with the access to the Internet, limited list of electronic services, sabotage by the government officials) and factors affecting the level of corruption (economic freedom, inflation, welfare level, political stability) are highlighted. Practical implication. The comparison of international indicators on the level of development of e-government and the level of corruption in Ukraine does not confirm such dependence, although there is a positive correlation between liberalization of the economic sphere and reduction of the level of corruption. Value/originality. The study shows that e-government as the tool to combat corruption can be effective only in combination with other means. Accordingly, the list and scope of electronic public services should be expanded; this could give impetus to further deregulation, which is a key component of economic freedom.
\end{abstract}

Key words: e-government, corruption, public administration, deregulation, political stability, democracy.

JEL Classification: D74, E42

\section{Introduction}

Overthelast decades, information and communication technologies have been actively involved in all fields of public life, as a result manners and established patterns of relationships undergo transformation, sometimes even radical. Public administration, gradually utilising new tools for data collection and processing, provision of information and services to citizens, is no exception. Obviously, such changes have affected in some way such traditional illness of the bureaucratic apparatus as corruption.

The issues of corruption and e-government are well-studied by domestic and foreign researchers (in particular, A. Bova (2006), I. Valiushko (2013), I. Kushnarov (2018), K. Layne (2001), A. Safonenko (2004), S. Seriohin (2009), D. Serra (2006), H. Singh (2007), and others). However, their interrelations have not been studied thoroughly. The relationship between e-government implementation and the level of corruption is scarcely studied in Ukraine, with the exception of teaching aids (Semenchenko \& Zhuravlov, 2011). Moreover, anti-corruption recommendations by various international organizations only briefly mention the benefits of implementing e-government services, while among the benefits of e-government, reducing corruption is considered a minor consequence. For example, the United Nations E-Government Survey (UN E-Government Survey, 2018) states that its greatest potential merit is transformation towards resilient societies (achieving sustainable development goals through accessibility to services for all), inclusivity (negative correlation between digital technology use and social exclusion is established, however an obstacle in this field is e-illiteracy or difficult network access) and disaster forecasting and better response.

\footnotetext{
Corresponding author:

${ }^{1}$ National Academy of Internal Affairs, Ukraine.

E-mail: TsutskiridzeM@gmail.com

${ }^{2}$ Classic Private University, Ukraine.

E-mail: berezaanatoliy@ukr.net
} 
The study of the relationship between e-government and corruption has become of increasing interest relatively recently. For example, a number of researchers, including N. Elbahnasawy (2012), K. Kim (2014), D. Shim (2008), believe that e-government is capable of reducing corruption in government, but J. Mistry and A. Jalal (2012) have been the first to prove this dependency: the findings of their study suggest that the use of ICT leads to corruption reduction. Moreover, in the analysis of 2003-2010, these authors found that the impact of e-government was higher in developed countries than in developing countries. M. Garcia-Murillo and R. Ortega analysed the corruption model developed by R. Klitgaard (1991), which included factors such as: number of governmental websites, monopoly power of the State, public officials' authorities and responsibility of bureaucracy (Garcia-Murillo \& Ortega). In the context of e-government initiation, transparency issues were studied by F. Bannister (2011), J. Bertot (2010).

The study of the relationship between these two phenomena is complicated due to the nature of corruption, which is difficult to observe and quantify. Therefore, in establishing the level of corruption, researchers have to use either subjective indicators (surveys of citizens and entrepreneurs about their experience of dealing with corruption cases), or apply complex, indirect indicators. Moreover, the disadvantages of this type of research are due to a large number of countries involved in comparing the experience thereof. On the one hand, expanding the research database creates the illusion of identifying common trends and, thus, minimizing the impact of country-specific characteristics. On the other hand, corruption is to a certain extent a cultural phenomenon linked to the mentality, political culture, ethical values of public officials, which are determined primarily by the context of a specific country. Therefore, the analysis of several international indicators in several countries has enabled D. Lupua and K. Lazar (2015) to argue that the more frequent use of e-government, the lower corruption. In particular, it can be assumed that a $1 \%$ increase in the e-government index has been able to lead to a $6.7 \%$ decrease in corruption in the EU member States and 6.3\% for non-EU countries. Analysis of changes in corruption data between 1999 and 2006 due to the use of information technology - the launch of e-government initiatives during this period - enables T. Andersen (2009) to conclude that the implementation of e-government significantly reduces corruption. However, the utilisation of the most relevant indexes, which determine the level of corruption and the level of e-government development, enables to confirm or refute the hypothesis of their correlation.

\section{Presentation of the main material}

Firstly, it should be determined how e-government can help counteract corruption. In general, three positive outcomes of the widespread introduction of electronic government services and access to information on government activities by citizens can be identified: depersonification, deregulation and transparency. Its main advantage is to depersonalize interaction between a government official and a citizen: it is during physical contact between them the former has opportunities for abuse of his/her position and, next, for bribery. In other words, the more public services are provided through electronic portals, the less opportunities for corrupt behaviour occur.

Secondly, an important point is a decrease in the number of powers of public officials, in particular, regarding the decision-making on public contracts, the purchase of goods or services from entrepreneurs. That is, e-government acts as a deregulator, limiting the ability of public officials to commit unlawful acts for personal gain. In other words, it is the physical interaction between the official and the citizens, considerable powers of the former to issue permits, to register, to conclude contracts for the purchase of goods or services at the expense of the public budget, are among key prerequisites for favourable conditions for corruption. However, this assumption is rather theoretical and logical since it is almost impossible to confirm it empirically because of the nature of corruption, which depends on a number of factors rooted in the cultural, legal, social, political and economic structure of society.

Thirdly, an important outcome of e-government initiation is an increase in the transparency of public authorities' activities, which, accordingly, reduces opportunities for corruption and increase the public's confidence in their activities (Grimmelikhuijsen, Porumbescu, Hong \& Im, 2013; Porumbescu, 2016 (1); Bertot, Jaeger \& Grimes, 2010; Porumbescu, 2016 (2)). Moreover, thanks to the availability of information, citizens and civil society organizations have effective instruments to control the activities of executive bodies at all levels of government and officials' decisions, including on spending public funds (Shim \& Eom, 2008).

Considering e-government as one of the important tools for combating corruption, S. Bhatnagar (2002) argues that by making rules more simple and transparent, e-government encourages citizens and businesses to question unsubstantiated procedures and their arbitrary application. Transparency and the right to access to public information are considered essential for democratic participation, strengthening trust in the government, preventing corruption, improving the accuracy of government information and providing information to citizens (Cullier \& Piotrowski, 2009).

Information technology is important for direct accountability: citizens can get direct access to information on the functioning of government institutions and use ICT for public debate. T. Northrup and S. Thorson (2003) argue that this form of accountability requires openness and reduces corruption. 
In turn, D. Shim and T. Eom (2008) reveal that countries that use e-government have achieved a reduction in corruption; in particular, in the fields of taxes and government contracts, e-government is a successful solution to corruption in many countries in Europe, Asia and America.

The potential of e-government to transform public administration (enhancing its efficiency, costeffectiveness, quality of service) and the behaviour of officials (increasing accountability and transparency of their activities) even enable some experts to argue that information technology has led to a paradigm shift in public administration practices, particularly at the municipal management level. In this context, Southern Korea's experience is illustrative (Porumbescu, 2013): the e-system, improving management of the capital Seoul (OPEN) (Porumbescu, 2016), provides any person at anytime and anywhere with the opportunity to apply (for permits, registrations, purchases, contracts, etc.) and track the status of their application. This reduces the abuse of officials with their administrative powers, intensifies the interaction between citizens and public authorities, increases the transparency of the activities of government bodies of State and increases the accountability of officials, because each step is fixed by a system that promotes trust in a specific body and legitimacy of the political regime as a whole.

For a successful implementation of an e-government projectas aninstrument to counteract corruption, a number of factors, which have a significant impact on its level in a particular country, have to be considered. This issue is especially relevant for developing countries, where the implementation of modern information technology faces the problems of weak telecommunications infrastructure and the inaccessibility of computer equipment to a large number of citizens. These are economic freedom, inflation, welfare level, political instability.

The level of economic freedom is one of the most important obstacles to the spread of corruption. A number of comparative studies, for example by P. Graeff (2003), M. Paldam (2002), and L. Pieroni (2013), have empirically confirmed this conclusion. As a multifaceted phenomenon, economic freedom includes components that exclude opportunities for corrupt practices. In general, this applies to cases where corrupt practices arise from the physical interaction between those who need public services and the officials who provide them. Bribes and kickbacks are illustrative. Deregulation is an economic freedom key component that eliminates such corruption. In different countries, comparison of the level of economic freedom will include a number of criteria, such as freedom from corruption, protection of property rights, tax freedom, financial freedom, investment freedom, trade freedom, free movement of labour, public expenditure and so on.

Economic freedom, enhanced by economic liberalism, weakens corrupt behaviour, encourages economic openness and prevents dangers in economic relations (Shen \& Williamson, 2005). R. Goel and M. Nelson (2005) have found that economic freedom is more important than political in reducing corruption. Economic liberalization, based on a high level of economic freedom, enhances significantly the positive impact of democratic procedures on reducing corruption (Saha, Gounder, \& Su, 2009). Liberal economic globalization promotes economic freedom and corruption reduction (Akhter, 2004) by forcing international trade participants to follow international rules and regulation of economic globalization, as a result, countries have to reduce domestic corruption (Sung, \& Chu, 2003).

W. Sandholtz and M. Gray (2003) have analysed 150 countries and concluded that the level of corruption in the country is highly dependent on participation in international trade. Using data of a 6-year period (2002-2005 and 2008) for 187 countries and analysis of data as a methodology, they have found that e-government reduces corruption worldwide. The authors recommend international bodies to support and facilitate the implementation of e-government in parallel with other anti-corruption measures (Shim \& Eom, 2008).

Inflation is an important factor contributing to the spread of corruption in government. Since high inflation reduces real income, if it is nominal (i.e., officials' salaries) and is not indexed, then when faced with a real decline in income, public officials may resort to corrupt practices to obtain additional profits. In poor countries with very limited access to computers and the Internet in the community, e-government is unlikely to influence corruption in times of high inflation.

With regard to welfare level, it is evident that rich countries have all the infrastructure needed to implement e-government, and a large proportion of the population is taking advantage of e-government capabilities. R. Abdel (2014) proves that wealth has a positive impact on the large-scale transition to e-government services. At the same time, numerous studies of the phenomenon of corruption illustrate that in prosperous countries its level is much lower than in developing countries.

A number of studies, such as those conducted by L. Pellegrini (2008) and D. Teisman (2000), mention political instability as one of conditions contributing to the spread of corruption practices in the country. Usually, political instability means poor efficiency of law enforcement agencies that, in the face of political uncertainty, are incapable of performing their duties professionally, and in particularly difficult situations instability leads to lawlessness. At the same time, recent revolutionary events in Ukraine, Georgia, and Egypt indicate that the corruption of the country's top leadership has become one of the causes of riots. The authors of Corruption and Peace reveal this causation and prove that increasing corruption in the police and the judiciary weakens directly the rule of law and thus intensifies internal conflict and leads to violence (Institute for Economics 
and Peace, 2015). However, corruption is not confined to individual authorities or branches of government. For example, a group of researchers led by F. Campante (2009) argues that political instability encourages government officials to embezzle public funds.

As an anti-corruption tool, e-government faces some potential obstacles or challenges, especially in the context of developing countries. The main challenge is limited public access to the Internet in these countries. For example, the Internet penetration in Africa and Asia is $39.8 \%$ and $51.9 \%$ respectively, which is less than the world average of $57.3 \%$ (Internet Users in the World by Regions, 2019). In such context, government network information and services cannot be expected to have a slight impact on the level of corruption. Moreover, access and utilisation of e-government will be of use for the urban dwellers of these countries, except for people of rural areas. This raises the issue of the digital divide in the societies of these countries, and the legitimate asymmetry and inequality in access to government information and government services.

Another obstacle to the effective use of e-government to counteract corruption is that online services are limited because they do not cover the full range of public services. For example, online services do not cover government officials (i.e. police and traffic officers) or bureaucrats in services that require physical interaction between the service provider and the citizen (teachers, caregivers, social workers, etc.).

In view of the potential inability of e-government to provide full government information and online services to most people in developing countries, its effectiveness in reducing corruption will be rather low. However, given these constraints, traditional media ( $\mathrm{TV}$, radio, media, etc.) can become more effective in providing government information and services to the public, monitoring the activities of officials and public authorities through journalistic investigations.

The third obstacle to the effectiveness of e-government in reducing corruption is the inclination of public officials to resist the implementation of networked public service and even to influence government projects failure (Aladwani, 2016). There are three reasons to explain the resistance of officials. First, the online public services abolish or at least diminish the administrative powers of officials. There is no place for grassroot-level officials with appropriate administrative powers in modern high-tech government, in which the street-level of bureaucracy is replaced by bureaucracy at the monitor level. According to M. S. Zouridis (2002), bureaucracy of the monitor level is a direct interaction of officials with citizens through a computer screen.

However, monitor-level bureaucracy itself dies out in favour of system-level bureaucracy when administrative authority is delegated to system developers and other officials involved in data processing. This delegation does not require personal contacts between citizens and officials, technical administrators (who simply operate between society and the system as support). The result of this process is the reduction of the number of public officials, named organizational disintermediation (rejection of intermediaries), when Internet systems increase the performance of public authorities by reducing the middle levels (Swiss, 2003).

Regarding e-government development in Ukraine, nowadays 119 citizens have access to e-services, presented on the Government portal (Official Website of Government portal for electronic services). Most of the services are available in categories as follows: Business, Land \& Ecology, Finance \& Tax, somewhat less in: Health \& Education, Security \& Court, Finance \& Tax, Transportation, Citizenship \& Migration, Construction \& Real Estate, Social Security. Citizens use e-services increasingly. For example, the noticeable growth of 2018, compared to the previous year, was recorded in the registration of childbirth assistance, that is, 25.8 thousand users (in 2017, 6.4 thousand), registration of a criminal record - up to 116.9 thousand (16.7 thousand), e-services for public registration of an individual entrepreneur (opening, closing, changing KVED) -14.8 thousand ( 5.5 thousand).

Regarding legislative support, the Concept of Development of the Electronic Service System in Ukraine (the Order of the Cabinet of Ministers of Ukraine No. 918-r dated November 16, 2016) was adopted in order to define the areas, mechanism and terms of formation of an effective electronic service system in Ukraine to satisfy the interests of individuals and legal entities through development and support of available and transparent, secure and non-corrupt, least-cost, fast and convenient electronic services. In addition to improving the quality of administrative services provided to citizens and businesses in line with the European requirements, increasing the efficiency of public authorities, the expected outcomes include a reduction in the risk of corruption in providing administrative services. Nowadays, 2019-2020 Action Plan for Implementation of the e-Services Development Concept in Ukraine is realised (the Order of the Cabinet of Ministers of Ukraine of January 30, 2019 no. 37-r).

It should be noted that in 2014 the Law of Ukraine "On the Principles of 2014-2017 Anti-Corruption Public Policy in Ukraine (Anti-Corruption Strategy)" (Law of Ukraine No. 1699-VII dated October 14, 2014) provided for a number of specific preventive measures to combat corruption in different areas, which involve and require utilisation of modern information and communication tools.

Therefore, e-government in Ukraine is relatively mature and grounds to find out its impact on the level of corruption in the country exist. The analysis involves data for Ukraine, such as: the E-Government Development Index, the Corruption Perceptions Index, the Economic Freedom Index, and the Ease of Doing Business Index. 
- the E-Government Development Index (United Nations E-Government Survey, 2018). According to the UN report, the E-Government Development Index considers three components: 1) the scope and quality of online services; 2) the status of the development of telecommunication infrastructure; 3 ) the status of domestic human capital;

- the Corruption Perception Index (Transparency International, 2018);

- the Economic Freedom Index, defined by the Wall Street Journal and the Heritage Foundation and takes into account components, such as freedom of business, investment, labour and trade, tax freedom, monetary freedom, financial freedom, protection of property rights and freedom from corruption;

- the Ease of Doing Business Index (The World Bank, 2020) is the World Bank Index that enables to compare the availability of business between countries. It is derived from the study of laws, regulations and rules regarding business activities, without consideration of external conditions, such as infrastructure, inflation and crime. In the context of the counteracting corruption, the most significant indicators specify the complexity of starting a business, obtaining a building permit, registering property, paying taxes, conducting international trade, closing a company.

According to the table, since 2014 Ukraine has shown stable positive dynamics in terms of reducing corruption, increasing economic freedom and ease of doing business. However, the level of e-government development has not managed to get closer to the indicator of 2010, due to changes in the methodology of index calculation or accelerated introduction of modern information and communication technologies into the public administration of other countries (or the slowdown of this process in Ukraine).

\section{Conclusion}

In the most general form, three positive effects can be identified from the widespread introduction of electronic government services and access to information on government activities by citizens: depersonification, deregulation and transparency. Its main advantage is the depersonification of the interaction between a government official and a citizen: it is during physical contact between them that opportunities for abuse of the first position and bribery of the second are created. In other words, the more public services provided through electronic portals, the less opportunities for corrupt behaviour.

For a successful implementation of an e-government project as a tool to counteract corruption, the following factors have to be taken into account, which have a significant impact on its level in a particular country. This issue is especially relevant for developing countries, where the introduction of modern information technology faces the challenges of poor telecommunications infrastructure and the inaccessibility of computer technology to a large number of citizens. These are economic freedom, inflation, the level of prosperity in society, political instability.

As an anti-corruption tool, e-government faces some potential obstacles or challenges, especially in the context of developing countries. The main challenge is that access to the Internet in these countries is very limited. Another obstacle to the effective use of e-government to counteract corruption is that online services are limited because they do not cover the full range of public services. The third obstacle to the effectiveness of e-government in reducing corruption is the inclination of public officials to resist the implementation of networked public service delivery and even to fail e-government projects.

We can talkabout the relative maturity ofe-government in Ukraine and the existence of grounds to find out its impact on the level of corruption in the country. The analysis of correlation between e-government and level of corruption in Ukraine is based on four criteria: E-Government Development Index, Corruption Perceptions Index, Economic Freedom Index, Ease of Doing Business Index.

The analysis of literature gives grounds to claim that e-government only in combination with other factors makes it possible to reduce the level of corruption. Accordingly, the list and scope of electronic public services should be expanded: this can give impetus to further deregulation, which is a key component of economic freedom. The correlation between e-government and corruption becomes more evident and produces a positive result once society has achieved a high level of economic growth and development. Further studies should include the analysis and indicators of the stability of countries and their degree of democracy, which indirectly indicates the level of corruption and real opportunities for citizens to participate in decisionmaking and control the activities of public authorities through the use of modern information technologies.

Table 1

Rating Dynamics (2009-2019)

\begin{tabular}{|l|c|c|c|c|c|c|c|c|c|c|c|}
\hline & 2009 & 2010 & 2011 & 2012 & 2013 & 2014 & 2015 & 2016 & 2017 & 2018 & 2019 \\
\hline Corruption Perceptions Index (the higher the better) & & & & 26 & 25 & 26 & 27 & 29 & 30 & 32 & \\
\hline E-Government Development Index (the lower the better) & & 54 & & 68 & & 87 & & 62 & & 82 & \\
\hline Economic Freedom Index (the higher the better) & 51.0 & 48.8 & 46.4 & 45.8 & 46.1 & 46.3 & 49.3 & 46.9 & 48.1 & 51.9 & \\
\hline Ease of Doing Business Index (the lower the better) & 145 & 142 & 145 & 152 & 137 & 112 & 96 & 83 & 80 & 76 & 71 \\
\hline
\end{tabular}




\section{References:}

Bova, A. (2006). Koruptsiia u suspilstvi, shcho transformuietsia: sotsiolohichnyi analiz [Corruption in a transforming society: a sociological analysis]. Politychnyi menedzhment, vol. 3, pp. 141-151.

Valiushko, I. V. (2013). Sotsialni chynnyky protydii koruptsii v Ukraini [Social factors of counteracting corruption in Ukraine]. Stratehichni priorytety, vol. 2, pp. 69-73.

Kushnarov, I. V. (2018). Politychna koruptsiia: porivnialno-politolohichna kontseptualizatsiia: monohrafiia [Political corruption: comparative political conceptualization: a monograph]. Kyiv: In-t derzhavy i prava im. V. M. Koretskoho NAN Ukrainy; Vydavnytstvo «Iurydychna dumka».

Layne, K., \& Lee, J. (2001). Developing fully functional e-government: a four stage model. Government Information Quarterly, vol. 18(2), pp. 122-136.

Safonenko, A. O. (2004). Antykoruptsiina polityka v umovakh transformatsii ukrainskoho suspilstva [Anticorruption policy in the conditions of transformation of Ukrainian society]. Avtoref. dys. ... kand. polit. nauk: 23.00 .02 . Kyiv.

Serohin, S. S. (2009). Antykoruptsiina derzhavna polityka: mizhnarodnyi dosvid [Anti-corruption state policy: international experience]. Derzhava ta rehiony, vol. 3, pp. 226-230.

Serra, D. (2006). Empirical determinants of corruption: a sensitivity analysis. Public Choice, vol. 126(1-2), pp. 225-256.

Singh, H., Das, A., \& Joseph, D. (2007). Country-level determinants of e-government maturity. Communications of the Association for Information Systems, vol. 20(1), pp. 632-648.

Semenchenko, A. I., \& Zhuravlov, A. V. (2011). Elektronne vriaduvannia yak efektyvnyi zasib u borotbi z proiavamy koruptsii: navch.-metod. materialy [E-governance as an effective tool in combating corruption: educational and methodological materials]. Kyiv: NADU.

UN E-Government Survey 2018. Retrieved from: https://publicadministration.un.org/egovkb/en-us/Reports/ UN-E-Government-Survey-2018

Elbahnasawy, N. G., \& Revier, C. (2012). The determinants of corruption: cross-country-panel-data analysis. J Dev Econ, vol. 50(4), pp. 311-333.

Kim, C. K. (2014). Anti-Corruption Initiatives and E-Government: A Cross-national Study. Public Organization Review, vol. 14(3), pp. 385-396.

Shim, D. C., \& Eom, T. H. (2008). E-government and anti-corruption: Empirical analysis of international data. International Journal of Public Administration, vol. 31, pp. 298-31.

Mistry, J. J., \& Jalal, A. (2012). An empirical analysis of the relationship between e-government and corruption. The International journal of digital accounting research, vol. 12(18), pp. 145-176.

Klitgaard, R. (1991). Controlling corruption. University of California Press.

Garcia-Murillo, Martha A. and Ortega, Rubén, Do E-Government Initiatives Reduce Corruption? (December 1, 2010). Available at: https://ssrn.com/abstract $=2012470$ or http://dx.doi.org/10.2139/ssrn.2012470

Bannister, F., \& Connolly, R. (2011). The trouble with transparency: A critical review of openness in e-government. Policy \& Internet, vol. 3(1), pp. 1-30.

Bertot, J. C., Jaeger, P. T., \& Grimes, J. M. (2010). Using ICTs to create a culture of transparency: E-government and social media as openness and anti-corruption tools for societies. Government Information Quarterly, vol. 27(3), pp. 264-271.

Lupua D., \& Lazar, C. G. (2015). Influence of e-government on the level of corruption in some EU and non-EU states. Procedia Economics and Finance, vol. 20, pp. 365-371.

Anderson, T. B. (2009). E-government as an anti-corruption strategy. Information Economics and Policy, vol. 21, pp. 201-210.

Grimmelikhuijsen, S., Porumbescu, G. A., Hong, B., \& Im, T. (2013). The effect of transparency on trust in government: A cross-national comparative experiment. Public Administration Review, vol. 73(4), pp. 575-586.

Porumbescu, G. A. (2016-1). Placing the effect? Gleaning insights into the relationship between citizens' use of e-government and trust in government. Public Management Review, vol. 18(10), pp. 1504-1535.

Bertot, J. C., Jaeger, P. T., \& Grimes, J. M. (2010). Using ICTs to create a culture of transparency: E-government and social media as openness and anti-corruption tools for societies. Government Information Quarterly, vol. 27(3), pp. 264-271.

Porumbescu, G. A. (2016-2). Linking public sector social media and e-government website use to trust in government. Government Information Quarterly, vol. 33(2), pp. 291-304.

Shim, D. C., \& Eom, T. H. (2008). E-government and anti-corruption: Empirical analysis of international data. International Journal of Public Administration, vol. 31, pp. 298-31.

Bhatnagar, S. C. (2002). E-government: Lessons from implementation in developing countries. Regional Development Dialogue, vol. 23(2), pp. 164-173.

Cullier, D. \& Piotrowski, S. J., 2009. Internet information-seeking and its relation to support for access to government records. Government Information Quarterly, vol. 26, pp. 441-449.

Northrup, T. A., \& Thorson, S. J. (2003). The Web of Governance and Democratic Accountability, in: R. Sprague (ed.), Proceedings of the 36th Hawaii International Conference on System Sciences, Hawaii. 
Shim, D. C., \& Eom, T. H. (2008). E-government and anti-corruption: Empirical analysis of international data. International Journal of Public Administration, vol. 31, pp. 298-31.

Porumbescu, G. A. (2013). Assessing the link between online mass media and trust in government: Evidence from Seoul, South Korea. Policy \& Internet, vol. 5(4), pp. 418-443.

Porumbescu, G. A. (2016). Comparing the effects of e-government and social media use on trust in government: Evidence from Seoul, South Korea. Public Management Review, vol. 18(9), pp. 1308-1334.

Kim, S., Kim, H. J., \& Lee, H. (2009). An institutional analysis of an e-government system for anti-corruption: The case of OPEN. Government Information Quarterly, vol. 26(1), pp. 42-50.

Graeff, P., \& Mehlkop, G. (2003). The impact of economic freedom on corruption: different patterns for rich and poor countries. European Journal of Political Economy, vol. 19, pp. 605-620.

Paldam, M. (2002) The cross-country pattern of corruption: economics, culture and the seesaw dynamics. Eur J Polit Econ, vol. 18, pp. 215-240.

Pieroni, L., \& d'Agostino, G. (2013) Corruption and the effects of economic freedom. European Journal of Political Economy, vol. 29, pp. 54-72.

Shen, C., \& Williamson, J. B. (2005). Corruption, democracy, economic freedom, and state strength a cross-national analysis. International Journal of Comparative Sociology, vol. 46(4), pp. 327-345.

Goel, R. K., \& Nelson, M. A. (2005). Economic freedom versus political freedom: Crosscountry influences on corruption. Australian Economic Papers, vol. 44(2), pp. 121-133.

Saha, S., Gounder, R., \& Su, J. J. (2009). The interaction effect of economic freedom and democracy on corruption: A panel cross-country analysis. Economics Letters, vol. 105(2), pp. 173-176.

Akhter, S. H. (2004). Is globalization what it's cracked up to be? Economic freedom, corruption, and human development. Journal of World Business, vol. 39(3), pp. 283-295.

Sung, H., \& Chu, D. (2003). Does participation in the global economy reduce political corruption? International Journal of Comparative Criminology, vol. 3(2), pp. 94-118.

Sandholtz, W., \& Gray, M. M. (2003). International integration and national corruption. International Organization, pp. 761-800.

Shim, D. C., \& Eom, T. H. (2008). E-government and anti-corruption: Empirical analysis of international data. International Journal of Public Administration, vol. 31, pp. 298-31.

Abdel, R. A. (2014). An empirical model of the adoption of web-enabled governmental services. International Journal of Business Research and Development, vol. 3(1), pp. 8-17.

Pellegrini, L., \& Gerlagh, R. (2008). Causes of corruption: a survey of cross-country analyses and extended results. Economics of Governance, vol. 9(3), pp. 245-263.

Treisman, D. (2000). The causes of corruption: a cross-national study. Journal of Public Economics, vol. 76, pp. $399-457$. Peace and Corruption. New York: Institute for Economics and Peace, 2015. URL: http://visionofhumanity.org/ app/uploads/2017/04/Peace-and-Corruption.pdf

Campante, Filipe R., Davin Chor, \& Quoc-Anh Do. (2009). Instability and the Incentives for Corruption. Economics and Politics, vol. 21(1), pp. 42-92.

Internet Users in the World by Regions - 2019. URL: http://www.internetworldstats.com/stats.htm

Aladwani, A. M. (2016). Corruption as a source of E-government projects failure in developing countries: a theoretical exposition. International Journal of Information Management, vol. 36(1), pp. 105-112.

Bovens, M., \& Zouridis, S. (2002). From street-level to system-level bureaucracies: how information and communication technology is transforming administrative discretion and constitutional control. Public Administration Review, vol. 62(2), pp. 174-184.

Swiss, J. E. (2003). Information technology as a facilitator of results-based Management in Government. In: Garson GD (ed) Public Information Technology: Policy and Management Issues. Idea Group Publishing, London.

Website of Government portal for electronic services. URL: https://www.kmu.gov.ua/ua/diyalnist/reformi/ efektivne-vryaduvannya/rozvitok-elektronnih-poslug

Concept of Development of the Electronic Service System in Ukraine (the Order of the Cabinet of Ministers of Ukraine of November 16, 2016 no. 918-r). URL: https://zakon.rada.gov.ua/laws/show/ru/918-2016$\% \mathrm{D} 1 \% 80 \# \mathrm{n} 8$

2019-2020 Action Plan for Implementation of the e-Services Development Concept in Ukraine is realised (the Order of the Cabinet of Ministers of Ukraine of January 30, 2019 no. 37-r). URL: https://zakon.rada.gov.ua/ laws/show/ru/37-2019-\%D1\%80

Law of Ukraine "On the Principles of 2014-2017 Anti-Corruption Public Policy in Ukraine (Anti-Corruption Strategy)". Law of Ukraine of October 14, 2014 no. 1699-VII. URL: https://zakon.rada.gov.ua/laws/show/1699-18

UN E-Government Survey 2018. URL: https://publicadministration.un.org/egovkb/en-us/Reports/UN-EGovernment-Survey-2018

Transparency International. Corruption Perception Index 2018. URL: https://ti-ukraine.org/research/indeksspryjnyattya-koruptsiyi-2018

The World Bank (2020). Doing Business project. URL: https://www.doingbusiness.org/en/doingbusine 